\title{
Type 1 Brugada pattern induced by DKA
}

\section{Drew Johnson}

MD Assistant Professor of Medicine Department of Medicine, Division of Cardiology Thomas Jefferson University Hospital, USA.

*Corresponding Author: Drew Johnson, 925 chestnut street, Mezzanine Philadelphia, PA 19007, USA.

Received Date: September 022021 | Accepted Date: December 152021 | Published Date: January 042022

Citation: Drew Johnson (2022). Type 1 Brugada pattern induced by DKA. Endocrinology and Disorders. 6(1): DOI:10.31579/2640-1045/106

Copyright: ( $) 2022$ Drew Johnson, this is an open-access article distributed under the terms of the Creative Commons Attribution License, which permits unrestricted use, distribution, and reproduction in any medium, provided the original author and source are credited.

A 25-year-old man with a past medical history of type 1 diabetes presented to the emergency department with 2 days of progressive abdominal pain, nausea, and vomiting after stopping insulin. His heart rate was 125 and the respiratory rate was 26 . The glucose was $832 \mathrm{mg} / \mathrm{dl}$, the potassium was $6.6 \mathrm{mmol} / \mathrm{L}$, the beta-hydroxybutyrate was 111.8 $\mathrm{mg} / \mathrm{dl}$, and the $\mathrm{pH}$ was 6.95 . The electrocardiogram (ECG) showed sinus tachycardia with anterior ST segment elevations, and a right bundle branch block pattern, consistent with Brugada type 1 pattern (Panel A). On review, his family history was unremarkable. The patient did have a history of three prior vagally-medicated syncopal episodes. The remainder of his history and physical exam were unremarkable. He was diagnosed with diabetic ketoacidosis and was given IV fluids and insulin.
Three hours later the glucose was $318 \mathrm{mg} / \mathrm{dl}$, the potassium was 4.5 $\mathrm{mmol} / \mathrm{L}$, and the $\mathrm{pH}$ was 7.18. A repeat ECG (Panel B) showed sinus tachycardia with resolution of the previously noted ST changes and right bundle branch block. The patient was diagnosed with Brugada type 1 pattern on his ECG. He was counseled about avoidance of excessive alcohol intake, aggressive treatment of fevers with antipyretics, counseled to treat future syncopal events as an emergency, asked to visit Brugadadrugs.org to review what medications are safe in Brugada syndrome, and scheduled for outpatient electrophysiology follow up for additional evaluation. Until he can undergo genetic testing for Brugada syndrome the patient is assumed to have Brugada syndrome.

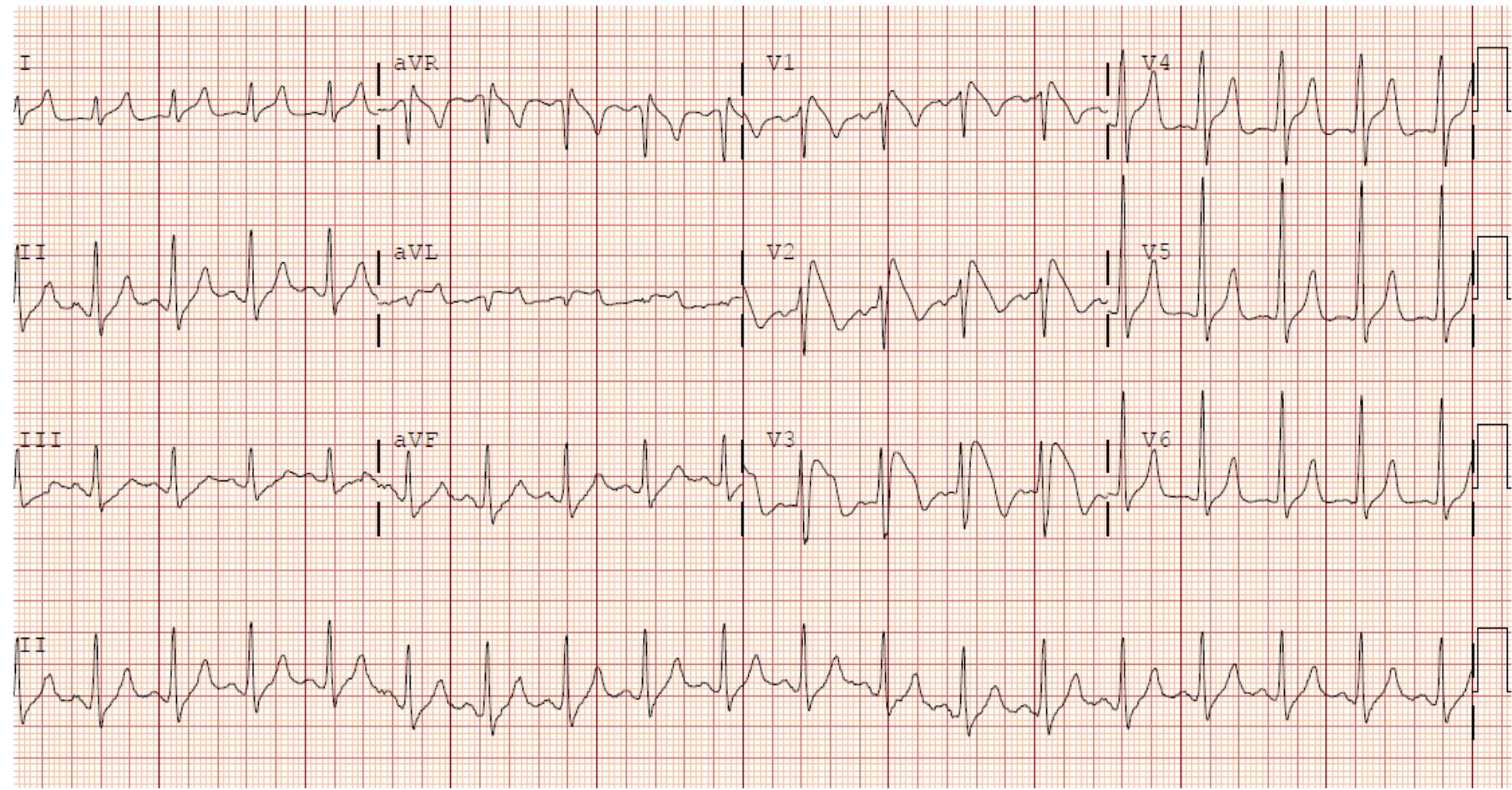

Panel A 


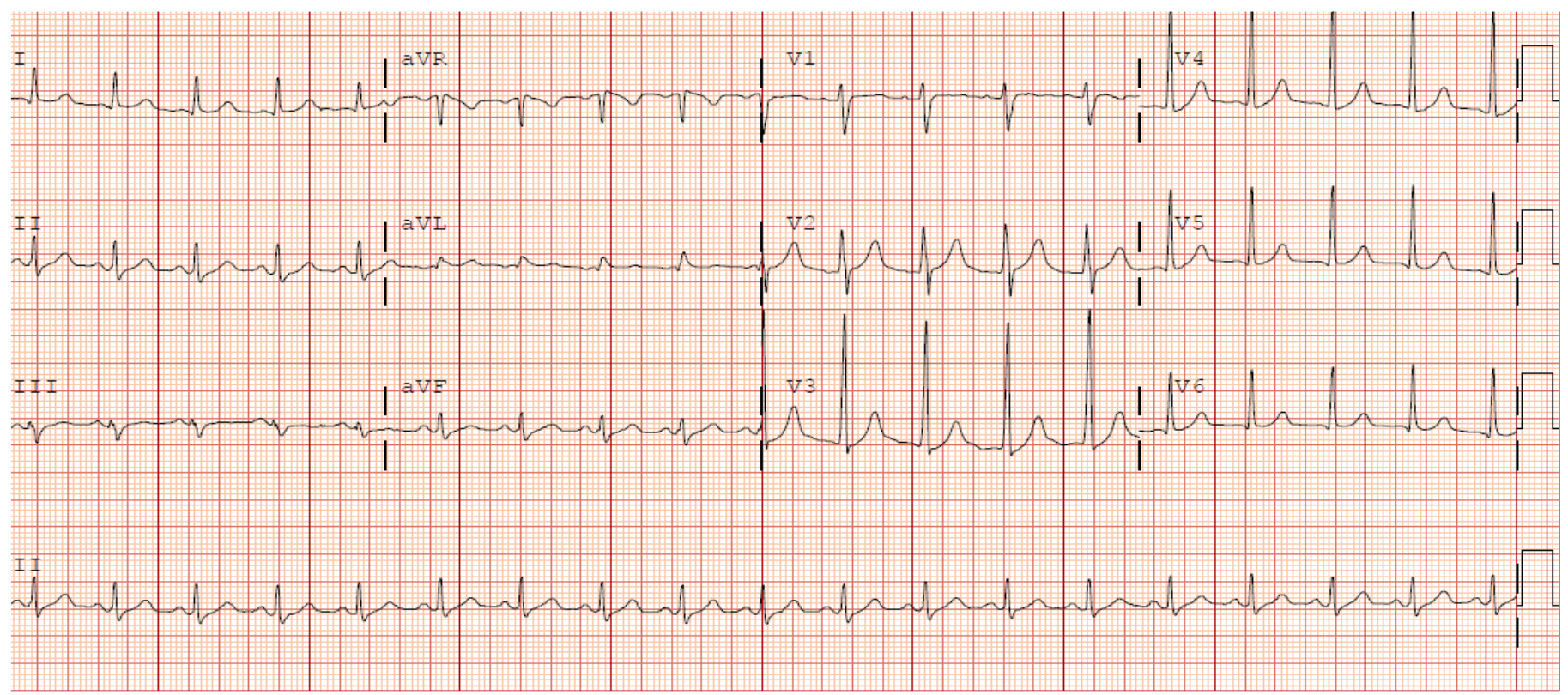

\section{Panel B}

Brugada syndrome is divided into three types. Type 1 is diagnosed when there is $>2 \mathrm{~mm}$ ST segment elevation in $\geq 1$ of the right precordial leads either $\mathrm{V} 1$ or $\mathrm{V} 2$, positioned in the $2^{\text {nd }}, 3^{\text {rd }}$, or $4^{\text {th }}$ intercostal space occurring either spontaneously or after provocative drug test with intravenous administration of class 1 antiarrhythmic drugs [1]. Brugada syndrome is a genetic condition that was first described in 1992 that increases patient's risk for sudden cardiac death [2]. The syndrome is most commonly caused by a mutation in the sodium channel SCN5A gene [3]. However, ECG and clinical manifestations are variable. ECG manifestations in particular may be intermittent. There are known triggers to finding a Brugada pattern on ECG including certain medications, fever, and metabolic conditions such as diabetic ketoacidosis. However, previous reports have shown that not all patients with documented Brugada pattern under severe metabolic derangement are able to demonstrate it spontaneously or with provocation testing [4]. There is currently no consensus about the management of patients with an incidentally noted Brugada pattern in the setting of a severe metabolic disturbance. The diagnostic criteria for Brugada syndrome include either a spontaneous pattern or one that is unmasked with pharmacologic provocation testing (specifically Class I anti-arrhythmics). We plan to treat this patient the same way we treat our other patient with Brugada syndrome.

\section{References:}

1. Priori, Silvia G., et al. (2014). "HRS/EHRA/APHRS Expert Consensus Statement on the Diagnosis and Management of Patients with Inherited Primary Arrhythmia Syndromes." Journal of Arrhythmia. 30(1):1-28.

2. Brugada P, Brugada J (November (1992). "Right bundle branch block, persistent ST segment elevation and sudden cardiac death: a distinct clinical and electrocardiographic syndrome. A multicenter report". Journal of the American College of Cardiology. 20(6):1391-1396.

3. Chen Q, Kirsch GE, Zhang D, Brugada R, Brugada J, Brugada P, Potenza D, Moya A, Borggrefe M, Breithardt G, Ortiz-Lopez R, Wang Z, Antzelevitch C, O'Brien RE, Schulze-Bahr E, Keating MT, Towbin JA, Wang Q. (1998). Genetic basis and molecular mechanism for idiopathic ventricular fibrillation. Nature. 392:293-296.

4. Kovacic, Jason C, and Dennis L. Kuchar. (2004). "Brugada Pattern Electrocardiographic Changes Associated with Profound Electrolyte Disturbance." Pacing and Clinical Electrophysiology. 27(7):1020-1023.

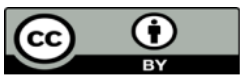

This work is licensed under Creative Commons Attribution 4.0 License

To Submit Your Article Click Here:

Submit Manuscript
Ready to submit your research? Choose Auctores and benefit from:

$>$ fast, convenient online submission

$>$ rigorous peer review by experienced research in your field

$>$ rapid publication on acceptance

$>$ authors retain copyrights

$>$ unique DOI for all articles

$>$ immediate, unrestricted online access

At Auctores, research is always in progress.

Learn more https://auctoresonline.org/journals/endocrinology-and-disorders 